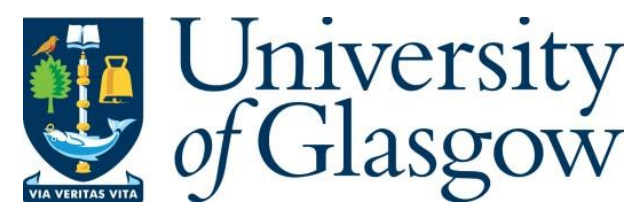

Maguire, J., Cutts, Q., Parkinson, J., Barr, M. and Somerville, D. (2019) Devising Work-based Learning Curricula With Apprentice Research Software Engineers. In: 24th Annual ACM Conference on Innovation and Technology in Computer Science Education (ITiCSE 2019), Aberdeen, Scotland, 15-17 Jul 2019, p. 313. ISBN 9781450363013.

There may be differences between this version and the published version. You are advised to consult the publisher's version if you wish to cite from it.

(C) The Authors 2019. This is the author's version of the work. It is posted here for your personal use. Not for redistribution. The definitive Version of Record was published in the Proceedings of the 2019 ACM Conference on Innovation and Technology in Computer Science Education, Aberdeen, Scotland, 15-17 Jul 2019, p. 313. ISBN 9781450363013. https://doi.org/10.1145/3304221.3325576.

\title{
http://eprints.gla.ac.uk/190281/
}

Deposited on: 12 July 2019

Enlighten - Research publications by members of the University of Glasgow http://eprints.gla.ac.uk 


\section{Devising Work-based Learning Curricula with Apprentice Research Software Engineers}

\author{
Joseph Maguire \\ University of Glasgow \\ Glasgow, United Kingdom \\ joseph.maguire@glasgow.ac.uk
}

\author{
Quintin Cutts \\ University of Glasgow \\ Glasgow, United Kingdom \\ quintin.cutts@glasgow.ac.uk
}

\author{
Jack Parkinson \\ University of Glasgow \\ Glasgow, United Kingdom \\ jack.parkinson@glasgow.ac.uk
}

\author{
Matthew Barr \\ University of Glasgow \\ Glasgow, United Kingdom \\ matthew.barr@glasgow.ac.uk
}

\author{
Derek Somerville \\ University of Glasgow \\ Glasgow, United Kingdom \\ derek.somerville@glasgow.ac.uk
}

\section{POSSIBILITIES AND PITFALLS}

There are many potential benefits from universities appointing apprenticeship RSEs for the purposes of curricula development:

- Reliable authentic assessment. The concern with some assessments is that while reliable, they are not valid as they are not informed by context [4]. Devising material with RSEs has the potential to increase validity while ensuring reliability.

- Relevant curriculum coverage and staging. The expectation is that apprentices should begin with legitimate peripheral participation, but this will require the academic partner to deliver valuable knowledge and skills as soon as possible. The expectation is that by working closely with research groups, lecturers gain experience in how to devise valid but relevant curriculum coverage and staging.

While there are potential benefits to the approach there are some concerns:

- Curriculum with limited scope. The scope and focus of the curriculum is a major concern when a university is essentially only 'talking to itself'. The shape of a RSE curriculum will be dependent on the breadth of disciplines and capabilities of research teams.

- Limited awareness of software engineering. The lack of exposure of generic industrial software engineering practices may result in a software engineer that has limited career progression outside of research.

\section{FUTURE WORK}

The initial project work has been investigating expectations of RSEs for a range of disciplines and plan for initial recruitment. The next stage is to devise appropriate structures to ensure curricula can be improved inline with the needs of the role.

\section{REFERENCES}

[1] Rob Baxter, N Chue Hong, Dirk Gorissen, James Hetherington, and Ilian Todorov. 2012. The Research Software Engineer. In Digital Research Conference, Oxford. 1-3.

Permission to make digital or hard copies of part or all of this work for personal or classroom use is granted without fee provided that copies are not made or distributed for profit or commercial advantage and that copies bear this notice and the full citation on the first page. Copyrights for third-party components of this work must be honored

For all other uses, contact the owner/author(s).

ITiCSE '19, July 15-17, 2019, Aberdeen, Scotland UK

(c) 2019 Copyright held by the owner/author(s).

ACM ISBN 978-1-4503-6301-3/19/07.

https://doi.org/10.1145/3304221.3325576

[2] Paul Gibbs. 2013. Work-based quality: a collusion waiting to happen? Quality in Higher Education 19, 1 (2013), 1-6. https://doi.org/10.1080/13538322.2013.777520

[3] Joseph A Raelin. 1997. A Model of Work-based Learning. Organization Science 8, 6 (1997), 563-578. https://doi.org/10.1287/orsc.8.6.563

[4] Geoffrey Scheurman and Fred M Newmann. 1998. Authentic intellectual work in social studies: Putting performance before pedagogy. Social Education 62 (1998), 23-26. 